\section{A Network System For the Flow of African Administrative Information Materials}

\author{
by Edward Seth Asiedu, ' \\ Chief, \\ Division of Documentation, CAFRAD, \\ Tangier, Morocco.
}

\section{Introduction}

Nearly three decades ago, the "wind of change" which blew over the African continent left in its wake spates of political agitation, and social movements and pressure groups seeking autonomy from their, then, metropolitan and colonial masters - namely, the British, the French, the Belgians, the Portuguese, and the Spanish.

The granting of independence to these countries brought with it great challenges to their civil services. A consequent change in the variety. number and complexity of government functions has emcrged, necessitating a thorough examination not only of the administrative machinery to facilitate the required expansion and modernization for accelerated economic and social development, but also, of training and orientation policies so that civil servants would be better able to meet the challenges posed by the accelerated momentum of change.

Durable administrative reforms and innovations, however, often depend upon research in theories and practices of government. Through administrative survevs, observations, analysis of research questionnaires, interviews, experiments, etc., data concerning inefficiency and corruption can be obtained. Data-collection or fact-finding is the first step towards bringing about administrative reform and creating innovations. If modern government in a developing setting is to accomplish its task and mission effectively and successfully, the administrators who will be required to assume these new governmental responsibilities should have adequate access to organized information to broaden their outlook and training in order to equip them with the capabilities they need.

Studies have shown that administrative sciences are basic to national development. The development of administrative and managerial skills and the application of modern management techniques in an African society faces a lack of adequate and reliable administrative information for making policy and administrative decisions and for analysis of problems. In most cases, the proper adminisurative information and documentation channels are lacking, thus hindering the transfer of the right amount and kind of information at the right place, to the interested user.

\footnotetext{
${ }^{1}$ Presented at IASSIST/IFDO International Conference May 1985, Amsterdam
} 


\section{Sources of administrative information}

What is administrative information? Briefly, let us define the parameters of administrative information. "Administration" may be defined as the achievement of an organizational objective through the use of men, money, materials and machines. "Information" is "a statement that describes an event (or an object or a concept) that helps us distinguish it from others". 2 By extension, therefore, "administrative information" is a meaningful statement about how men, money, materials and machines are managed to achieve the objectives of an organization. In other words, administrative information could be described as information related to administration, designed in general terms, as a set of data necessary to understand institutions, make decisions and to participate in them, in order to produce the goods and services required by the community.

In the African context, however, information on Public Administration is in reality attached to information on "Development Administration". Despite the disagreements on an exact definition of "development administration", most students, scholars, and practitioners involved in the development process in Africa agree that information on the following subjects fall within the mandate of "Development Administration:

namely,

- development planning and plans;

- administrative reform;

- public enterprise management;

- training of administrators;

- research in administrative systems; and
- socio-cconomic data.

It would also include materials dealing with the administrative and management aspects of the functional areas of the productive sectors e.g. agriculture, industry, eonomic development, etc...

Administrative information sources are usually in the form of pamphlets and report literature, surveys, statistical data, case studies, issuances and other such like documents. A large number of these forms are government publications. Government documents or publications are the living record of the efforts of people to govern themselves. The responsibilities of government extend over many aspects of a citizen's life, work, and leisure and, in the course of administrative control, the agencies of the government collect a vast amount of information. Much of this collected data is of potential value to research workers in economics, social, scientific and technological subjects. Government publications range, in size, from pamphlets to ponderous volumes; and in content, they vary from articles with popular appeal to technical treatises of value. Taken as a whole, they constitute a great library covering almost cvery ficld of human knowledge and endeavor. Some of these publications may be transcripts of origina! records and therefore constitute primary source material in the history of government administration and activities. Others contain accounts by administrative or executive officers on the work and activities under their direction, e.g. annual reports of departments, bureaux, etc... Voluminous series published by other agencies also present statistical pictures of socio-economic conditions and afford bases for measuring social and economic change.

2 Eilon, S. Management control. New York, MacMillan, 1971, pp. 98. 


\section{The flow of administrative materials}

Data cannot exist if not generated. Therc is evidence that African governments are bccoming more and more prolific in their output of official documents, published and unpublished. The remarkable transformation of postwar Africa, accelerated in the past two decades or so, has created many problems in the field of government publications. There have been extensive constitutional, governmental and administrative changes, ministerial and departmental "re-re-organizations", and alterations in policies governing publishing of official documents. It is becoming increasingly difficult to identify what is available. Whilst in the colonial days, it was easy to acquire the bulk of the official publications from African countries, now it is quite a problem to trace, not to mention acquire, a government document from each other. The reason is obvious - the absence of a plausible, systematic bibliographic control. In-depth research ${ }^{3}$ carried out by the speaker in 1977 aimed at studying the generation, production, control, availability and utilization of African Government Documents provides ample information on the situation referred to above.

Another research survey ${ }^{4}$, carricd out on the provision of library facilities in government departments in a typical African country identified one major draw-back to the improvement of the situation - namely, the lack of financial support and/or importance accorded by African government's to this area. An

\footnotetext{
3 Asiedu, E.S. African governments: the case of West African english speaking countries: Gamiba, Ghana, Liberia. Nigeria \& Sierra Leon. Tangier, Morocco, CAFRAD, 1978.

${ }^{4}$ A siedu, E.S. "Organizing the flow of Administrative Information in a developing setting: a proposal for the Ghana Public Services". In Greenhill Joumal of Administration, Vol.1. \#3. Oct-Dec.74, pp.39-56.
}

examination of budget estimates ${ }^{5}$ for a four-year period (1971-72/1974-75) revealed some interesting facts. Whilst a few of the Ministries, Departments etc... had huge amounts respectable enough for the establishment, maintenance and running of a library, many others run on votes which look very miserable indeed. In most cases the library votes are hidden under such headings or codes as: "other office expenditures": "office expenses": "ncwspapers";... Worse still, others are found under "toilet papers, stationary and library"; "newspapers and rent of office soap" - a clear indication that libraries, or for that matter the organization of administrative information and literature, are very much frowned upon by the civil service - the very people who need data in their day-to-day occupations. Albeit, it is encouraging to observe that in the last five or so years some improvements have been made in this direction.

The financial situation alluded to above explains the paltry and disorganized condition of the libraries of African government departments. With such an appalling state of affairs, how can proper information be obtained, which information may be vital for the formulation of a major governmental policy? It is pathetic that often most Ministries and Dcpartments lack complete collections of their own publications! Very often, a better organized library outside the governmental system is called upon to satisfy inquiries from Ministries about their own publications! It is amazing to find that a foreign library has everything that African governments have issued - published or unpublished - from the earliest times to the present. African scholars and research fellows have had to travel outside the continent to consult such materials, at great expense to the taxpayer. This situation cannot continue forever; the time is overdue for something more concrete to be initiated.

\footnotetext{
$s$ See Annexure
} 


\section{The "ANAI" concept}

The last twenty five years have witnessed a continued growth of educational and training institutions of public administration and management. Also Civil Service Commission and agencies have been inaugurated to carry out different phases of administrative reform in their respective countries. These are manned by capable African experts who are mainly involved in applying and disseminating their know-how, experience, and knowledge to the African administrative environment. Over the past fow years their activities have resulted in the production of vast quantities of documents often mimeographed reports, government documents and other sorts of publications. These documents describe existing conditions, define goals, describe programmes and projects, and evaluate the consequences of any adminisuative action and decision. In addition, African administrative science researchers and trainers study administrative processes, generate training materials and publish their findings and conclusions in journals, research reports and other media issued in Africa and elsewhere.

It is quite fair to say that this growing litcrature of administrative sciences is not yet under adequate bibliographic control and it is exceedingly difficult to know how to obtain access to the information and experiences which have been investigated in print. With this growth of African administrative information comes an increasing demand to know about African experiences in the various aspects of administrative and managerial development.

It is an awareness of this situation, as well as the realization that no one African country can ever hope to become self-sufficient in the face of an expanding universe of administrative information, that the African Training and Research Centre in Administration for Development (CAFRAD) has, in keeping with one of its constututional mandates, and in concert with African governments, initiated the African Network of Adminstrative Information (ANAI) - a description of which follows:

\section{Objectives of ANAI}

ANAI is aimed at bringing together materials from different African perspectives on administrative sciences as they rclate to the African coninent and bringing together literature which may have been gathered by different African libraries and/or documentation centres, but which provide in their combination a new and much greater resource, and synthesizing and disseminating the collected data at regular intervals and upon request.

Thus, the objectives of ANAI are:

- to improve co-ordination between the cxisting African administrative information services - i.e. libraries/ documentation centres of institutions and agencies of public administration and management:

- to foster the improvement and building of national administrative information services or systems;

- to supplement local collections by drawing more effectively on African external resources:

- to avoid unnecessary duplication and waste of resources;

- to provide a referral service for enquiries from organizations both inside and outside the African continent;

- to serve more users and improve national, 
regional and international access to Alrican administrative and managerial experience and knowledge:

- to make administrative information uniformly available and

- to change the image of the African library from that of a store of books to that of an active and dynamic information centre.

\begin{abstract}
ANAI, as proposed, would imply a degree of diffusion and popularization of administrative information services, a steady increase in the ability to serve at all points of service, and co-operative sharing withoul constraint of time, distance or form of data. Also, it is intended to minimize the financial pressures which are facing African administrative information activities, and to consider ways of sharing rather than duplicating materials and other resources. It encourages building appropriate local administrative collections to meet immediatc needs. It is also devised in such a way as to make readily available distant collections in other African countries. ANAl is aimed also at motivating the utilization of modern miniaturization and computerization techniques in the storage and retricval of administrative information.
\end{abstract}

research workers in the domain of the administrative sciences. Also, it is expected that the system will extend its services to any user interested in African administrative and managerial development anywhere in the world, without any restriction on access.

With regard to the subject coverage, ANAI is designed to deal with specialized materials on public administration and management with respect to the African continent. It will encompass data pertaining to topics such as: local government, rural and urban development, administrative reform, project management, financial management, human resources development, etc... As a mission-oriented system, ANAl would have to include relevant multi- and inter-disciplinary information sources in as much as it has a role in the amelioration and improvement of African administrative and managerial development.

The administrative information materials to befed into ANAI may be recorded in a wide range of media formats: printed forms; audio-visual forms; machine-readable forms (punched cards, magnetic tapes); microphotographic forms (fiches/films). These materials should be mainly generated in Africa, or elsewhere if they are confined to the subject coverage in the African context.

Organizational structure

Scope and coverage

ANAI, as seen from the preceeding paragraphs, is a specialized system limited to special categories of users and confined to specific locations. It is anticipated that ANAI will serve a wide variety of users who fall into many categories such as: governmental and other administrative managers; policy makers; educators and trainers; trainees and students;

\begin{abstract}
ANAI is envisioned to function as an African region-wide decentralized information system with a network of (for the time being) three interrelated lines of operation, namely:
\end{abstract}


1. regional central clearing-house (CAFRAD)

2. national administrative information focal points

3. Jocal libraries and documentaton centres of ministries, departments, bureaux etc...

It is envisioned that a fourth operational line or organizational level could be inserted between regional and national levels to represent a "sub-regional" level, but this development will depend on the magnitude of growth of ANAI in the future.

Brief descriptions of the functions of these levels follow:

\section{- Regional central clearing-house:}

will function as a coordinating agent of the whole network. It will develop and set out technical methods, procedures and standards for the whole network. It will also develop, revise, maintain and unify its indexing language in thesaurus of administrative informatin descriptors; forms for input data. and dissemination channels for output products. It will maintain a data base of information needed, perform miniaturization, microfilming and microfiching of textual input data; and issue guides, directories, abstracts and indexes. It will develop training programmes for the information and documentation personnel of member states and also provide specialist consultancy services to governments as and when required.

- National administrative information focal points:

These national focal points represent the national participants of ANAI. They would be libraries and/or documentation centres designated by their governments. The rolc of these national focal points will be to furnish the Regional Clearing-House with local data on administrative and managerial development. These will include input data on institutions and agencies, training programmes, consultants and trainers, training materials, and current research activities which will constitute the data base of the Regional Central Clearing-House.

Each National Focal Point would assist in mobilizing and co-ordinating the national resources and services of administrative information systems. This policy is in conformity with the recent recommendation promoting the creation of national information systems (NATIS) made by the "Inter-Governmental Conference on Nationa] Libraries, Documentation and Archives Infrastructure" which was organized by UNESCO, JFLA and FID and held in Paris in September 1974, and also with the UNECA Conference of Ministers' resolution $\mathrm{N}^{0} 359$ (XIV) of the 14th Session held in Rabat, Morocco.

National Focal Points will be the main suppliers to the Regional Clearing-House of the rclevant textual documents, acquisition lists and abstracts. In return, the NCPs will get all ANAJ publications, directories, guides, bibliographies, indexes, microfilming services and other dissemination tools pertinent to administrative information.

\section{- Local libraries \& documentation centres:}

These will include libraries and other such information units within the civil service organizatons like ministries, bureaux, dcpartments and other state agencies and institutions of public administration and management. These local centres will feed the National Focal Points with their materials and also collabourate with them to 
identify and supply their input contributions to the Regional Central Clearing-House.

Diagramatically. the organizational structure of ANAI looks like this:

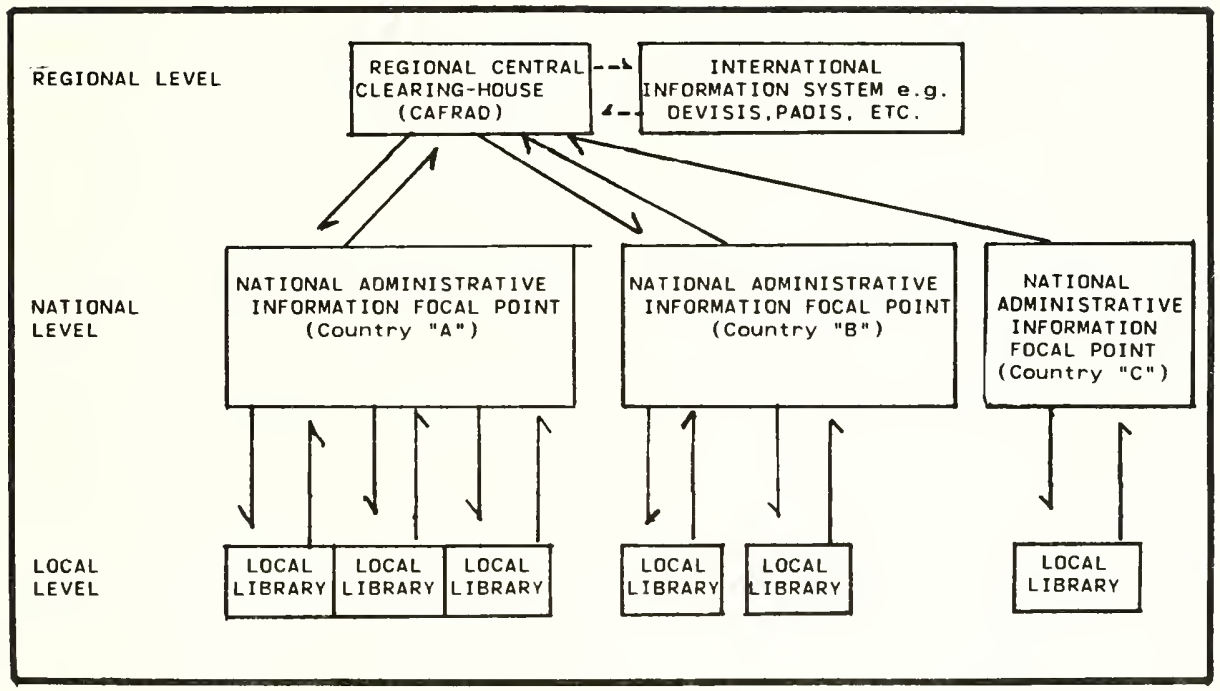

This kind of organizational relationship could assist in bringing together the African adminisurative literature under national and regional bibliographic control and this in turn will surely assist and facilitate the identification of resources and access to them. It will also cnsure the success of co-ordinating. managing and operating ANAI. 


\section{ANAI output}

ANAI would ensure output of required data in the required form at the required time to a specific user. This would include the production of specialized guides and directories represented in the different data files stored in the data base, as well as periodic regular abstracts, indexes and specialized bibliographies which represent the current awareness services to users. It will also furnish answers to multiple queries. There will be back-up service of microfiche copies of the full texts of documents identified in the indexes, abstracts and other bibliographies disseminated through the output operation.

Diagramatically this output will look like this:

\begin{tabular}{|c|c|c|}
\hline \multirow[t]{5}{*}{ Ditectones \& Files } & \multicolumn{2}{|l|}{ - Insututions/Agencies } \\
\hline & \multicolumn{2}{|l|}{ - Training Programmes } \\
\hline & \multicolumn{2}{|l|}{ - Training Materıals } \\
\hline & \multicolumn{2}{|c|}{ - Consultants \& Tramers } \\
\hline & \multicolumn{2}{|c|}{ - Current Rescarch Projects } \\
\hline \multirow[t]{5}{*}{ Output Products } & $\begin{array}{c}\text { Current Awareness } \\
\text { Service }\end{array}$ & $\begin{array}{l}\text { - Monthly Indexes } \\
\text { - Quarterly Abstracts } \\
\text { - Specialized Bibliographies }\end{array}$ \\
\hline & Quten: & Aณwe゙ \\
\hline & \multicolumn{2}{|c|}{ Reprography Services - Photostats/Xeros } \\
\hline & & - Microfiching \\
\hline & & - Pnnung \\
\hline
\end{tabular}

Conclusion

An improved network of African administrative and managerial development needs a high-speed, reliable information system. The conventional means of professional communication, i.e. libraries. provide coverage that is neither complete nor timely, especially as regards research proposed or on-going, as well as decision-making process.

The evolution of a voluntary association of existing libraries and documentation centres of administrative information services in Africa, each preserving its own management autonomy, offers a realistic basis for creating ANAl. Therefore, the ANAI project can be viewed as a regional movement towards increased voluntary cooperation among national partner focal points with varying degrees and modalities of interconnection.

This regional network could be further developed into a world administrative information system that provides current reports on all significant findings, activities and planning affecting any part of the network. For that ultimate goal, the development of ANAI could emerge in conformity and in line with experience gained from the existing international information systems and within the conceptual framework of UNESCO's World Science Information System (UNISIST) programme.

Early this year (January 1985) I.D.R.C. (editor's note: International Development Research Centre) of Canada responded to C.AFRAD's call for financial support to enable it to implement a pilot project code-named "ANAI

EXPERIMENTAL" for a three-year period to test the operational system of ANAI. We are very grateful to the centre for this demonstration of confidence in us. However, there is room for further assistance.

May I, therefore, crave your indulgence to make an appeal, on behalf of CAFRAD: to this august body; to development institutions here present; to other donor agencies world-wide, to collabourate with CAFRAD, to assist CAFRAD, to share with CAFRAD their expertise and financial resources to ensure the germination, growth and fruition of the ANAI seed.

ㅁ 
Library Note Statistics

\begin{tabular}{|c|c|c|c|c|c|}
\hline Department & $1971 / 72$ & $1972 / 73$ & $1973 / 74$ & $1974 / 75$ & Remarks \\
\hline Transport \& Communication & & 100.00 & 6000.00 & 6000.00 & Including Regions \\
\hline Auditor-General & & 146.00 & 3400.00 & 4400.00 & \\
\hline Trade \& Tourism & & & 1700.00 & 5000.00 & \\
\hline Agriculture & 1000.00 & & & 3000.00 & \\
\hline Town \& Country Planning & 100.00 & & 800.00 & & \\
\hline National Fire Service & 500.00 & 700.00 & 760.00 & 2000.00 & \\
\hline Social Welfare \& Com. Dev. & & 500.00 & 500.00 & & \\
\hline Police Service & 600.00 & 900.00 & 1500.00 & 2200.00 & $\begin{array}{l}\text { Including education } \\
\text { instruction materials }\end{array}$ \\
\hline Internal Affairs (Central Admin.) & & & & & \\
\hline Prison Service & 300.00 & 400.00 & 400.00 & 400.00 & $\begin{array}{l}\text { Subscription to } \\
\text { Ghana Library Board } \\
\text { \& Prison Library } \\
\text { Service }\end{array}$ \\
\hline Foreign Affairs & & 12000.00 & 8800.00 & 10000.00 & \\
\hline Posts \& Tele-communications & & & & & \\
\hline Local Government (Cent. Admin.) & & & 660.00 & 4000.00 & \\
\hline NRC (General Administration) & & 3000.00 & 3000.00 & 10000.00 & $\begin{array}{l}\text { Includes Capital vote } \\
\text { of } 2730.00\end{array}$ \\
\hline NRC (Press Secretary) & & & 5000.00 & 5000.00 & \\
\hline NRC (Chieftaincy) & & 1000.00 & 3000.00 & 4500.00 & \\
\hline National Council for Higher Edu. & & & & 5000.00 & \\
\hline NRC (Annex) & - & 1300.00 & 4000.00 & 6000.00 & \\
\hline NRC (MSD) & - & 6000.00 & 4000.00 & 2000.00 & \\
\hline NRC (PIB) & 130.00 & 380.00 & 1000.00 & 1400.00 & \\
\hline Regional Organizations & - & 1920.00 & 5220.00 & 6600.00 & $\begin{array}{l}\text { No vote for Ashanti } \\
\text { \& Upper Regions fot } \\
\text { 1974/75 }\end{array}$ \\
\hline Parliament House & 2000.00 & 500.00 & 1000.00 & - & \\
\hline Establishment Secretariat (Training) & 800.00 & 3200.00 & 1000.00 & - & \\
\hline Public Service Commission & 100.00 & 200.00 & 200.00 & & For Newspapers only \\
\hline Information (Central Admin.) & 1250.00 & 1900.00 & 1900.00 & 2000.00 & \\
\hline Information Services Department & - & 2800.00 & 7640.00 & 6000.00 & \\
\hline Informaion Services (Regions) & - & 1400.00 & 1000.00 & 3000.00 & \\
\hline Attorney-General's Department & 3500.00 & $32,000.00$ & 8000.00 & 8000.00 & Including Regions \\
\hline Judicial Services & $55,900.00$ & $53,000.00$ & $22,140.00$ & 25.820 .00 & \\
\hline Registrar-General's Department & 100.00 & 400.00 & $1,000.00$ & $1,000.00$ & \\
\hline Central Revenue & & - & $1,410.00$ & $10,000.00$ & \\
\hline Finance and Economic Planning & $70,000.00$ & $60,000.00$ & ? ? & $56,500.00$ & $\begin{array}{l}\text { Including } 3 \text { other } \\
\text { Divisions }\end{array}$ \\
\hline
\end{tabular}

